\title{
MAKNA RITUAL MANAJAH ANTANG BAGI KEHIDUPAN MASYARAKAT DAYAK KATINGAN DI KASONGAN
}

\author{
The Meaning of the Manajah Antang Ritual for the Life of the Dayak Katingan \\ Community in Kasongan
}

\author{
Sumiatie \\ *IUniversitas PGRI Palangka \\ Raya, Palangka Raya, \\ Kalimantan Tengah, Indonesia \\ *email: \\ sumiatie.mpd@gmail.com
}

\begin{abstract}
Abstrak
Kalimantan Tengah yang didiami oleh berbagai suku, seperti suku Dayak ngaju Ma'anyan, Lawangan, Dusun dan sebagainya yang mempunyai keanekaragaman adat istiadat, tradisi dan budaya yang merupakan cerminan dari kekayaan daerah Kalimantan Tengah. Adapun suku yang dibicarakaan dalam penelitian ini adalah suku Dayak Katingan, Kebanyakan dari suku ini mendiami sungai Katingan (Mandawai) dan sebagian besar masih memeluk agama Kaharingan, dengan salah satu tradisinya yaitu Upacara Adat Tradisional Manajah Antang. Upacara tradisional ini merupakan upacara yang sifatnya turun temurun dengan mengundang antang tajahan. Menurut kepercayaan Dayak Katingan, antang tajahan berbeda dengan burung antang biasa, dimana antang tajahan tersebut memiliki kesaktian yang dapat memberi petunjuk atau pertanda dan pertolongan kepada manusia. Tujuan yang ingin dicapai dalam penelitian ini adalah untuk mendriskripsikan makna Ritual Manajah Antang bagi kehidupan masyarakat Dayak Katingan di Kasongan. Pendekatan yang digunakan dalam penelitian ini adalah metode deskriftif dalam bentuk kualitatif dengan Teknik pengumpulan data berupa observasi partisipasi atau pengamatan terlibat serta komunikasi langsung dalam bentuk wawancara. Berdasarkan hasil analisa dan interprestasi bahwa tujuan penyelenggaraan Upacara Adat tradisional Manajah Antang di anggap mengandung makna untuk membantu mengatasi kesulitan masyarakat, dapat menimbulkan rasa aman, bisa memberikan petunjuk, dapat membawa keselamatan bagi yang melakukan perjalanan jauh sehingga sampai ketujuan, dapat meningkatkan kehidupan sosial masyarakat, serta dapat memberikan penghidupan yang lebih layak dalam membuka lahan bagi masyarakat.

Abstract

Central Kalimantan, which is inhabited by various tribes, such as the Dayak ngaju Ma'anyan, Lawangan, Dusun and so on, which have a diversity of customs, traditions and cultures which are a reflection of the richness of the Central Kalimantan region. The tribes spoken in this study are the Dayak Katingan tribe. Most of these tribes inhabit the Katingan river (Mandawai) and most of them still embrace the Kaharingan religion, with one of its traditions, the Manajah Antang Traditional Ceremony. This traditional ceremony is a ceremony that hereditary by inviting antang tajahan. According to the Dayak Katingan belief, the antang tajahan is different from the ordinary antang tajahan bird, which the antang tajahan has the power to give instructions or signs and help humans. The aim of this research is to describe the meaning of the Manajah Antang Ritual for the life of the Dayak Katingan people in Kasongan, Katingan Regency. The approach used in this research is descriptive method in a qualitative form with data collection techniques in the form of participatory observation or involved observation and direct communication in the form of interviews. Based on the results of analysis and interpretation that the purpose of organizing the Traditional Manajah Antang Ceremony is considered to contain meaning to help overcome community difficulties, able to create a sense of security, able to provide guidance, able to bring safety to those who travel far so that they reach their destination, able to improve the social life of the community, and able to provide a more decent living in clearing land for the community.
\end{abstract}

\section{Kata Kunci:}

Makna I

Ritual 2

Manajah Antang 3

Published

April 2021
(C) 202IThe Authors. Published by Institute for Research and Community Services Universitas Muhammadiyah Palangkaraya. This is Open Access article under the CC-BY-SA License (http://creativecommons.org/licenses/by-sa/4.0/). 


\section{PENDAHULUAN}

Mengingat bangsa Indonesia memiliki keanekaragaman suku bangsa, adat istiadat dan tradisi untuk menghindari kepenuhan diperlukan pembinaan dan pengembangan lebih lanjut, oleh sebab itu perlu mendapat perhatian yang lebih serius baik dari masyarakat maupun dari pemerintah selaku subjek budaya. Diantara sekian banyak keanekaragaman adat, istilah adat dan tradisi yang berupa kebudayaan adalah upacara adat tradisional Manajah Antang. Untuk masyarakat Kalimantan Tengah upacara adat Manajah Antang merupakan kebudayaan peninggalan nenek moyang suku Dayak Katingan yang sampai kini masih diakui.

Kalimantan Tengah yang didiami oleh berbagai suku, seperti suku Dayak ngaju Ma'anyan, Lawangan, Dusun dan sebagainya yang mempunyai keanekaragaman adat istiadat, tradisi dan budaya yang merupakan cerminan dari kekayaan daerah Kalimantan Tengah. Adapun suku yang dibicarakaan dalam penelitian ini adalah suku Dayak Katingan, Kebanyakan dari suku ini mendiami sungai Katingan (Mandawai) dan sebagian besar masih memeluk agama Kaharingan, dengan salah satu tradisinya yaitu Upacara Adat Tradisional Manajah Antang. Upacara tradisional ini merupakan upacara yang sifatnya turun temurun dengan mengundang antang tajahan. Menurut kepercayaan Dayak Katingan, antang tajahan berbeda dengan burung antang biasa, dimana antang tajahan tersebut memiliki kesaktian yang dapat memberi petunjuk atau pertanda dan pertolongan kepada manusia.

Upacara ini biasanya diselenggarakan manakala terjadi peristiwa alam seperti Gerhana matahari, Gerhana Bulan, Gempa Bumi, dan peristiwa alam lainnya. Adapun maksud dari penyelenggaraan upacara manajah Antang ini adalah untuk mencari petunjuk atau pertanda agar masyarakat terhindar dari berbagai bencana. Upacara Manajah Antang ini telah dilaksanakan secara turun temurun yang berkaitan dengan kepercayaan suku Dayak Katingan. Pelaksanaan Upacara adat tradisional Manajah antang hampir tidak berbeda jauh dengan pelaksanaan upacara adat lainnya, hanya terdapat variasi tambahan seperti syarat-syarat, tahapan-tahapan serta waktu dan tempat pelaksanaannya, yang disesuaikan dengan maksud tujuan diselenggarakan upacara ini.

Dengan pesatnya pembangunan di Kalimantan Tengah dari semua aspek kehidupan yang membawa berbagai perubahan pola pikir masyarakat sehingga membawa dampak terhadap kebudayaan daerah seperti adat tradisi diantaranya upacara adat tradisional Manajah Antang yang semakin memunah keberadaannya ditengah-tengah masyarakat Dayak Katingan. Bahkan sekarang ini banyak masyarakat yang tidak mengetahui tentang upacara adat Manajah Antang khususnya di kalangan anak muda dan anak-anak. Agar tradisi ini tidak hilang dan punah harus ada peran dari pemerintah, masyarakat, tokoh adat dan kepala adat agar kelak dapat diwariskan ke anak cucu.

Adapun masalah yang peneliti kemukakan dalam penelitian ini adalah "Apakah makna upacara adat tradisional Manajah Antang bagi kehidupan Masyarakat Dayak Katingan di Kasongan?”.

Tujuan yang ingin dicapai dalam penelitian ini adalah untuk mendriskripsikan makna Ritual Manajah Antang bagi kehidupan masyarakat Dayak Katingan di Kasongan Kabupaten Katingan. Manfaat dari hasil penelitian ini diharapkan bermanfaat bagi masyarakat untuk mengetahui makna ritual Manajah Antang bagi masyarakat Dayak Katingan di kasongan dan mampu ikut melestarikan adat tradisional Manajah Antang yang sudah mulai menghilang dari kehidupan masyarakat Katingan.

Ritual Manajah Antang berasal dari kata “Tajah antang”. Kata Manajah pada upacara tradisional Manajah Antang berasal dari kata dasar "Tajah” yang berarti "Tanda atau Alamat", yang selanjutnya kata dasar ini mendapatkan awalan "Ma" yang membentuk kata kerja "Manajah" yang berarti "mencari pertanda 
atau petunjuk". Sedangkan kata "Antang" itu sendiri diartikan dalam bahasa Dayak Katingan adalah "Burung Elang” (Elang yang bersifat sakti).

Jadi menurut Drs. Kiwok D.Rampai (1984:63), dalam bukunya Upacara Tradisional dalam kaitannya dengan peristiwa alam dan kepercayaan daerah Kalimantan Tengah yang dimaksud dengan upacara manajah Antang adalah:

“Upacara Tradisional dengan mengundang burung elang dengan mempelajari gerak gerik dan tingkah laku dari burung elang ini memberikan tanda-tanda tentang apa yang akan terjadi”.

Kemudian di katakan lebih lanjut bahwa:

"Upacara ini biasanya dilaksanakan berkaitan dengan peristiwa alam dan kepercayaan seperti adanya gerhana bulan akan terjadi suatu penceklik di bidang pertanian dan sebagainya" (1984:83).

Dengan memperhatikan pendapat di atas, yang dimaksud dengan ritual Manajah Antang adalah merupakan satu ritual tradisional dari warga masyarakat Suku Dayak Kalimantan Tengah. Ritual ini bersifat turun temurun yang erat kaitannya dengan kepercayaan dan keyakinan akan adanya kekuatan rohroh yang berada di luar kekuatan manusia yang mampu memberikan bantuan atau petunjuk manakala mereka mengalami kesulitan dalam kehidupan.

Kesulitan atau masalah yang mereka hadapi dimaksud yang berkaitan dengan kejadian alam maupun dalam kehidupan sehari-hari manakala mereka mengalami masalah tersebut yang merupakan ancaman atau bahaya sehingga mereka memerlukan perlindungan yang dapat memberikan petunjuk kearah keselamatan bersama. Oleh sebab itu dengan ritual Manajah Antang inilah merupakan salah satu dari upacara tradisional yang menurut kepercayaan atau keyakinan mereka mampu menjawab atau mencari jawaban keluarganya agar mencapai keselamatan dimaksud.

Ritual Manajah Antang dilakukan kapan saja manakala terjadi suatu peristiwa atau bencana atau mungkin juga musibah yang menurut kepercayaan masyarakat Katingan sangat kurang menguntungkan bagi kehidupan mereka bersama, maka mereka mencari jalan keluar guna mencapai keselamatan bersama dimaksud, mereka menyelenggarakan ritual Manajah Antang.

Dalam masalah peristiwa alam yang sering terjadi, misalnya gerhana matahari atau gerhana bulan, paceklik dan lain sebagainya. Dengan menyelenggarakan Ritual Manajah Antang, masyarakat suku Dayak katingan yakin bahwa segala sesuatu yang berkaitan dengan permasalahan dalam kehidupan mereka akan terselesaikan melalui petunjuk antang dimaksud. Ritual ini bertujuan mengetahui:

I. Di mana tempat yang menguntungkan jika akan berusaha

2. Ke mana arah merantau yang menguntungkan

3. Di mana tempat berladang yang baik

4. Bagaimana cara mengobati sakit seseorang

5. Di mana tempat yang cocok untuk membangun kampung

6. Dalam hal terjadinya peperangan

7. Dalam hal mencari tempat terjadinya musibah

Ritual Manajah Antang ini dapat dilaksanakan pada hari dan bulan apa saja. Yang paling baik yaitu pada saat cuaca terang dan diusahakan pada waktu pagi hari menjelang tengah hari (metuh matan andau mandai), juga dapat dilaksanakan sesudah tengah hari asal cuaca masih terang. Untuk hal apa saja Ritual Manajah Antang dilakukan, saat cuaca terang dan bersih sehingga kehadiran antang tajahan dapat dilihat dengan jelas.

\section{METODOLOGI}

Bogdan dan Taylor (dalam Moleong, 20I2:2I) menyatakan metode deskriptif kualitatif sebagai prosedur penelitian yang menghasilkan data deskriptif berupa kata-kata tertulis atau lisan dari orang-orang dan perilaku yang dapat diamati. Prosedur pada penelitian ini, yaitu observasi, pemilihan narasumber 
penelitian, wawancara, pencatatan data berdasarkan perekaman lisan, pengolahan data, analisis data, penyusunan laporan akhir.

Pendekatan yang digunakan dalam penelitian ini adalah metode deskriftif dalam bentuk kualitatif dengan Teknik pengumpulan data berupa observasi partisipasi atau pengamatan terlibat serta komunikasi langsung dalam bentuk wawancara dengan nara sumber mengenai makna Ritual Manajah Antang Bagi Kehidupan Masyarakat Dayak Katingan di Kasongan Kabupaten Katingan. Adapun yang menjadi narasumber adalah Demang Kepala adat, Mantir Adat, Tokohtokoh Adat dan Masyarakat Adat Dayak katingan.

Analisis yang digunakan dalam penelitian ini adalah analisis interaktif. Miles dan Huberman (1984) mengemukakan bahwa aktivitas dalam analisis data kualitatif secara interaktif dan dilakukan secara terus menerus sampai tuntas, sehingga datanya sudah jenuh (dalam Sugiyono, 2013: 91). Dalam model analisis ini, tiga komponen analisisnya yaitu reduksi data, sajian data, dan penarikan kesimpulan atau verifikasi, aktivitasnya dilakukan dalam bentuk interaktif dengan proses pengumpulan data sebagai suatu proses yang berlanjut, berulang, dan terus-bergerak di antara komponen analisis dengan pengumpulan data selama proses ini masih berlangsung. Selanjutnya peneliti hanya bergerak diantara tiga komponen analisis tersebut.

\section{HASIL DAN PEMBAHASAN}

\section{Maksud Penyelanggaraan Upacara Adat}

\section{Manajah Antang}

Suku Dayak Kalimantan Tengah pada dasarnya hampir tidak berbeda jauh dengan sukusuku yang ada diwilayah Nusantara ini, hal ini dapat dilihat dari kepercayaan-kepercayaan nenek moyang mereka yang turun temurun percaya akan hal-hal gaib yang berada di luar batas kemampuan manusia. Oleh sebab itu manakala terjadi suatu kejadian yang dirasakan oleh masyarakat Dayak Kalimantan Tengah umum dan masyarakat Suku Dayak Katingan diluar alam pemikiran yang memiliki kekuatan yang dahsyat, seperti peristiwa gempa bumi, gerhana matahari, gerhana bulan dan sebagainya yang menurut kepercayaan Dayak Katingan selalu akan diikuti oleh berbagai bencana atau musibah yang akan menimpa masyarakat suku Dayak. Oleh sebab itu masyarakat suku Dayak Kalimantan Tengah selalu mencari jalan keluar untuk mencapai suatu keselamatan, maka dari itu mereka selalu berusaha agar musibah dan bencana dimaksud dapat teratasi. Adakalanya mereka menurunkan berbagai cara yang dapat dilakukan baik melalui kegiatan-kegiatan ritual ataupun melalui berbagai mimpi-mimpi yang menurut kepercayaan suku Dayak yang merupakan petunjuk dari Tuhan. Disamping cara tersebut ada juga yang mencari cara melalui suatu kekuatan gaib yang menurut mereka suatu kekuatan yang ada diluar rasa batas kemampuan manusia dalam upaya mengatasi bencana agar mereka dapat selamat.

Menurut Drs. Kiwok D. Rampai dalam bukunya Upacara Tradisional dalam Kaitannya dengan Peristiwa Alam dan Kepercayaan Daerah Kalimantan Tengah bahwa "salah satu usaha dan cara mereka untuk mencapai keselamatan bersama adalah dengan menyelenggarakan Upacara Manajah Antang".

Dengan melaksanakan usaha yang berupa upacara adat tradisional Manajah Antang yang merupakan salah satu usaha menurut kepercayaan suku Dayak Katingan. Adapun maksudnya ingin mengetahui akan bencana atau musibah merusak keselamatan bersama, dimana dengan 
melaksanakan upacara ini mereka mengharapkan akan mendapatkan tanda-tanda atau petunjuk tentang bencana apa yang akan menimpa mereka dan bagaimana cara untuk mengatasinya.

Setelah melaksanakan upacara adat tradisional Manajah Antang, suku Dayak Katingan yakin bahwa segala bentuk permasalahan atau bencana atau bencana yang akan menimpa akan dapat teratasi berdasarkan tanda-tanda atau petunjuk yang didapatkan dari pelaksanaan upacara adat tradisonal Manajah Antang yang didapat dari Antang Tajahan.

\section{Tahap-Tahap Penyelenggaraan Upacara}

\section{Tradisional Manajah Antang}

Dalam pelaksanaan upacara adat tradisonal Manajah Antang hamper tidak berbeda jauh dengan pelaksanaan upacara adat tradisonal lainnya. Diantaranya tahapan-tahapan pelaksanaan diatur sedemikian rupa sehingga penyelengaraannya dapat terlaksana dengan baik dan benar.

Tahapan-tahapan pelaksanaan upacara adat tradisional Manajah Antang sebagai berikut:

I. Pemebentukan panitia kecil pelaksanaan upacara adat tradisional Manajah Antang

Sebelum dimulainya penyelenggaraan upacara adat tradisional Manajah Antang terlebih dahulu dilakukan pembentukan panitia kecil dengan maksud agar pelaksanaan penyelenggaraan ini benar-benar dapat terlaksana dengan baik.

Adapun dalam pembentukan panitia kecil sebagai penyelenggaraan upacara ini terlebih dahulu dilakukan dengan cara musyawarah adat, maksudnya mengumpulkan para tetua adat pada tempat yang telah ditentukan untuk membicarakan atau siapa-siapa yang bertanggung jawab akan terselenggaranya upacara ini seperti pimpinan upacara, pembantu pimpinan upacara serta pembantu-pembantu lainnya yang bertugas mengatur pada bagian-bagian yang telah ditentukan.

2. Penetapan waktu pelaksanaan penyelanggaraan upacara

Dalam pelaksanaan penyelanggaraan upacara adat tradisional Manajah Antang pada dasarnya dapat dilaksanakan bulan apa saja dan kapan saja diperlukan karena sifatnya tidak terikat dengan ketentuanketentuan tertentu. Namun pada waktu pelaksanaan diselenggarakan paada pagi hari sesuai dengan peristiwa dan kebutuhannya, yakni kejadiaan-kejaadiaan yang terjadi dalam masyarakat. Hal ini sesuai dengan pendapat $\mathrm{Hal}$ ini sesuai dengan pendapat Demang Kepala Adat bahwa "biasanya upacara ini dilaksanakan pada pagi hari sampai menjelang tengah hari saat matahari naik".

Dikatakan lebih lanjut oleh Demang Kepala Adat:

"Dalam hal yang menyangkut kekacauan, perang dan baleh bunu (membunuh untuk membalas dendam, balas pati) maka upacara Manajah Antang ini dilaksanakan pada sore hari".

Sekalipun dalam pelaksanaan penyelanggaraan upacara adat Manajah Antang tersebut sifatnya tidak mengikaat saat-saat tertentu, kecuali ada hal-haal kebutuhan tertentu seperti kata Demang Kepala Adat. Namun pada umumnya 
penyelenggaraan upacara adat ini dipilih waktu yang tenang, hari yang terang, matahari yang tidak terlindung oleh kabut/awan. Pada umumnya oleh masyarakat Dayak Katingan dianggap paling baik yang dikembalikan pada maksud dan tujuan upacara tersebut.

3. Tempat penyelenggaraan upacara

Sebagaimana penentuan waktu atau saat pelaksanaan upacara adat tradisional Manajah Antang pada dasarnya tidak terikat dengan ketentuan tempat yang khusus dimana akaan dilaksanakan upacara ini. Dalam penentuan tempat penyelenggaraan dapat dilaksanakan dimana saja sesuai dengan kebutuhan masyarakat Dayak Katingan.

Sekalipun dalam penentuan tempat penyelenggaraan tidak ada ketentuan yang khusus, namun pada umumnya suku Dayak Katingan dalam menentukan tempat penyelenggaraan didasarkan pada tradisi yang sudah turun temurun dilaksanakan dalam penentuan tempat penyelenggaraan.

Seperti yang dikemukakan oleh Drs. Kiwok D. Rampai dalam bukunya Upacara Tradisional dalam Kaitannya dengan Peristiwa Alam dan Kepercayaan Daerah Kalimantan Tengah dalam kaitannya dengan peristiwa alam dan kepercayaan daerah Kalimantan Tengah bahwa:

Berdasarkan tradisi yang dianut maka tempat yang sesuai dan serasi adalah tempat yang biasa dipergunakan untuk upacara ini secara turun temurun oleh leluhur mereka dan merupakan tempat yang angker serta dihuni oleh roh-roh (gana) atau lebih dikenal dengan istilah bahasa Dayak Ngaju Eka Bagana (tempat berpenghuni) yang dikenal sebagai pukung tajahan antang.

Berdasarkan pendapat diatas, sangat jelas bahwa dalam penentuan tempat penyelenggaraan upacara tradisional Manajah Antang tidak ada ketentuan khusus dari masyarakat Dayak Katingan. Akan tetapi hanya didasarkan pada tradisi leluhur nenek moyang, dimana tempat yang serasi dan sesuai seperti yang dikutip dari pendapat diatas. Hal ini berdasarkan musyawarah dari seluruh masyarakat yang akan menyelenggarakan upacara adat tradisional Manajah Antang.

4. Pelaksanaan kegiatan upacara

Pelaksanaan kegiatan upacara adat tradisional Manajah Antang yang pertamatama dimulai dari kegiatan Upacara manawur. Upacara ini dimaksudkan untuk memanggil atau memberitahukan roh-roh yang akan dipergunakan pada upacara pokok Manajah Antang.

Adapun jalannya upacara manawur ini biasanya langsung dipimpin Demang, Kepala Adat pada waktu yang ditentukan dilengkapi denganbahan-bahan yang sudah ditentukan seperti beras tabor dan sebagainya.

Pimpinan upacara duduk bersila memandang lurus kedepan menghadap kearah pambelum yaitu arah kehidupan, arah matahari terbit dengan membaca mantramantra, agar segala mahluk halus yang berupa roh-roh (gana) penghuni tanah dilokasi yang dipergunakan untuk upacara 
Manajah Antang, tidak mengganggu jalannya upacara, bahkan diharapkan mereka juga ikut membantu mensukseskan terselenggaranya upacara tersebut. Maka sebagai imbalannya bagi mahkluk halus (roh-roh tersebut) diberikan makanan yang digantung dipohon dalam Ancak, inilah yang dimaksudkan dengan upacara marasih petak.

5. Setelah upacara marasih petak dilanjutkan dengan acara mampendeng patinju, mampendeng yaitu mendirikkan, patinju yaitu tiang-tiang atau patok bendera sebagai pembantu utama yang juga sebagai pembimbing dalam mengartikan gerak gerik dari tingkah laku antang. Dalam mendirikan patok, jumlahnya selalu ganjil sebanyak tiga, lima atau tujuh batang dari tiap patinju atau patok yang dihiasi dengan bendera warna warni yang mempunyai makna tersendiri yang disesuikan dengan maksud upacara tersebut.

6. Setelah mendirikan patinju selesai, acara dilanjutkan yaitu acara persiapan akhir yakni menilai apakah segala persiapan sudah siap dan tersedia semuanya yang meliputi bahanbahan sajian yang berupa telor behas tawur, sirih pinang, rokok dan limun atau air putih.

7. Setelah semua persiapan dinilai sudah tersedia dengan lengkap, kemudian upacara tradisional Manajah Antang dimulai dengan dibunyikannya atau di iringi dengan kelompok musik tradisional yang dilengkapi dengan sarana yang berupa alat gong, kangkanung, kecapi serta diiringi dengan lagu tradisional karungut dan juga diadakan pembakaran dupa atau kemenyan.
8. Setelah alat musik dibunyikan serta diiringi dengan lagu karungut dimulailah Upacara adat tradisonal Manajah Antang, pimpinan upacara disertai oleh tetua adat datang ketempat upacara yang kemudian diikuti dengan pemeriksaan kelengkapan upacara setelah dianggap cukup, pimpinan memberikan tanda megangkat tangan yang berarti upacara dapat dimulai.

Kemudian pimpinan upacara duduk bersila menghadap pambelum (matahari terbit) dengan membaca mantra-mantra sebagai tanda puji dan syukur terhadap Ranying Hatala Langit dan sekaligus mohon restu dari para dewa.

Selanjutnya pimpinan upacara mengambil beras tawur (beras kuning) dalam upaya mengundang antang tajahan agar bersedia datang. Beras kuning ditabur tujuh kali setelah membaca mantra-mantra dan kemudian dilanjutkan dengan tiga kali taburan beras kuning yang kemudian dilanjutkan dengan hadirin diajak oleh pimpinan upacara untuk melahap dan manukiw (bersorak secara adat suku Dayak) disertai bunyi-bunyian.

Dan apabila antang tajahan yang dipanggil tidak berhalangan maka dalam waktu yang relatif singkat ia akan datang dan jika berhalangan bisa diganti dengan antaang yang lainnya.

9. Kedatangan antang tajahan dan ramalan gerak geriknya

Setelah upacara dilakukan dan ternyata antang tajahan yang dipanggil datang, maka para petugas yang telah ditentukan khusus 
para tetua adat yang telah memiliki pengalaman terhadap gerak gerik antang tajahan yang menurut kepercayaan suku Dayak Katingan merupakan petunjuk bagi mereka dalam pemecahan masalah yang dihadapi.

Oleh sebab itu para tetua yang dianggap mampu oleh masyarakat menterjemahkan gerak gerik antang tajahan, kini sibuk mengamati setiap gerak geriknya sekecil apapun. Dari gerak gerik antang tajahan ini nanti dirangkaikan menjadi sebuah berita atau petunjuk yang dapat menjawab masalah yang sedang mereka hadapi.

Dengan demikian menurut kepercayaan suku dayak Katingan, dari apa yang digunakan dalam gerak gerik oleh antang tajahan tersebut, yang diterjemahkan oleh tetua masyarakat yang ditunjuk sebagai peterjemah ternyata selalu diyakini kebenarannya oleh masyarakat suku Dayak Katingan sehingga dengan demikian upacara adat tradisional Manajah antang ini selalu dilakukan oleh masyarakat Dayak Katingan daalam kaitannya apabila mereka menghadapi kesulitan yang berkaitan dengan peristiwa alam.

Beberapa antang yang senantiasa dapat hadir apabila diundang atau dipanggil:

I) Antang Rahu Batuyang Bunu Bahekan Riak Janjaliu Babulu Bulau atau Sangkalemu (dari muara suangai Kahayan)

2) Antang Panglima Raden Cili Mawa Tahanjungan Bukit Raya (dari Bukit Raya)

3) Antang Kameluh Bulau Pintun Janjingan Karawang Sambang Bukit Bundang (dari puruk Bundang di hulu sungai Laung)
4) Antang Sangkalemu Bukit Batu Barumbai Bulau Hataraju Hantantali Liu (dari Bukit Batu dekat Kasongan)

5) Antang Rawing Ranying Tatah Bukit Kaminting Antang Nyaluluk Luhing Lunuk Hai Hakaja Pating (dari riam Batu Hanyi daerah Kahayan Hulu)

6) Antang Raden Jaya Lamundi Gunung Kaki Riak Lalambungan Batu Hanyi (dari riam Batu Hanyi daerah Kapuas Hulu)

7) Antang Raden Tamunu Tunggun Lewu Bukit Walu Panjaga Riam Batu (dari Riam Kanan, Kalimantan Selatan)

8) Antang Tumbang Kahayan Antang Pandih Batu Panjang Hariran Panglima Paranggasan Pulau Kantan (dari Pangkuh, Pandih Batu)

9) Antang Tamanggung Kantan Sangiang Balai Lewu Tanjung Hanyi Karangan Penyang (dari Kantan, Pulang Pisau)

10) Antang Raden Pati Pulau Tabuan Salat Danau Tapang Kalambungan Lamiang (dari Pulau Tabuan Danau Tapang, Kuala Kapuas)

II) Antang Saliba Antang Penyang Pulau Kambang (dari Pulau Kambang, Banjarmasin)

12) Antang Pangeran Marunjat Intan Antang Nyai Ratu Bawi Kanaruhan Datuh Nyantagi Mirang Batang Danum Hurui Bunu Luwuk Kantan (dari Luwuk Kantan, Pulang Pisau)

I3) Antang Haramaung Antang Tamanggung Batu Kurung Puruk Batu Suli (dari Batu Suli, Tumbang Manange Kahayan) 
14) Antang Tamanggung Ranying Bukit Kangandang Gajah Kereng Kanungkan Hajaran (tidak jelas tempatnya, tapi sering mau datang)

15) Antang Tumbang Antang Batu Basauh Balai Sangkalemu Panjagan Tumbang Katingan (dari muara sungai Katingan)

16) Antang Kuwu Batu Banama Manihang Agung Antang Marasambung Bukit Tangkiling Teras Batu Nyaluluk Luhing (dari Bukit Tangkiling, Palangka Raya)

17) Antang Batinting Penyang Antang Rumbai Raja Kalambungan Lamiang Pulau Tapang (dari Pulau Tapang, Kapuas Hilir)

18) Antang Antang Kacapiring Kambang Pamatang Pinang Busung Baras Hasansulang Danau Layang (dari Danau Layang, Pulang Pisau)

19) Antang Raden Tunjung Alam Namburak Bulau Sangkalemu Antang Balingan Pulu Mahapilik Jalatien (tidak jelas tempatnya, tapi bersedia dipanggil)

20) Antang Tantaulang Bulan Kambang Andau Bagentu Jimat Kanaruhan Bukit Lamandau (dari daerah Lamandau, Kotawaringin Barat)

21) Antang Narasumbung Antang Tamanggung Babulu Tandang Kapanduian Danum Panyai Sangiang Basilu Mandau Tahan Manahan Kayau (dari Luwuk dalam Betawi, Pulang Pisau)

22) Antang Punggu Babulu Rambu (dari Manen Paduran, Kahayan)

23) Antang Tamanggung Tahunjung Tumbang Pandih (dari Manen Paduran, Kahayan)
24) Antang Manelapati Antang Tamanggung Ratu Tinggi (dari pukung tajahan antang dekat Pulang Pisau)

\section{Pantangan-pantangan yang harus dihindari}

Mengingat upacara Manajah Antang ini dilaksanakan dalam upacara yang bersifat sakral atau magis maka ada beberapa pantangan yang tidak dapat dihindari, walaupun sanksi-sanksi yang riskan tidak pernah diungkapkan tetapi akibatnya adalah tidak hadirnya antang tajahan pada upacara tersebut.

Di samping itu, adanya kepercayaan bahwa pelanggaran atas pantangan-pantangan ini akan membawa tulah dan nasib buruk di kemudian hari. Adapun pantangan-pantangan dimaksud ialah :

I) Tidak dilaksanakan upacara marasih petak jika mempergunakan tempat atau tanah baru untuk keperluan upacara Manajah Antang akan mangakibatkan hal-hal yang tidak diinginkan.

2) Senda gurau yang wajar tidak dilarang, tetapi senda gurai yang diucapkan secara porno tidak diperkenankan.

3) Kemungkinan terjadinya kekeliruan dalam mempersiapkan bahan atau peralatan seperti bahas tawur yang dipergunakan keliru, misalnya bahas bahenda melainkan behas bahandang bahenda akan fatal juga dengan akibat elang tidak mau datang.

4) Tempat atau tanah yang sudah dibersihkan harus dipelihara tetap bersih dalam arti dilarang berbuat sesuatu yang bersifat tulah.

Makna yang terkandung dalam unsur-unsur upacara 
Dalam upacara Manajah Antang ini dimana pelaksanaannya dilakukan secara sakral magis maka terdapat unsur-unsur yang bersifat lambanglambang atau simbol-simbol yang dapat kita catat.

Antang atau burung elang merupakan salah satu burung yang dianggap sakti oleh suku dayak di Kalimantan Tengah disamping burung tingang (enggang) dan burung tiung (beo). Burung elang perlambang dari kekuatan, ketangkasan dan kecermatan di mana semua itu tercermin dari sayapnya yang kuat, kaki dan kuku cengkramannya yang kokoh serta pandangan matanya yang tajam dan keberaniannya yang tak kenal takut.

Kebanyakan orang-orang terkemuka sukusuku Dayak mempergunakan gelar antang seperti Singa Antang, kepala desa batu Nyiwuh dan Antang Taui, pemimpin suku Dayak di hulu sungai Rungan dan Antang Kalang di hulu sungai Mentaya.

Di samping itu juga, tarian atau gerak gerik antang tajahan sering melambangkan suatu hal yang indah (lambang keindahan) contohnya adalah ikat kepala cara adat ngaju yakni seni mengikat kepala dengan kain yang dinamakan lawung yang dilakukan dengan benar akan menciptakan suatu keindahan tersendiri yang tergambar dalam ungkapan sastra daerah (tandak) sebagai berikut : Lawung baki kepala tinggi suntun anak antang manari, lawung kampung kawung kepanakan pangeran parabu anom, dan di dalam bahasa Sangiang juga terdapat kalimat :

\section{Lawung singkap antang, luhing angkul timpung.}

Patinju atau rahasan antang pada upacara Manajah Antang diikat daun sawang (lenjuang) dan boleh pula ditambahi kain warna warni dan biasa pula dipergunakan warna dasar yang disebut menurut agama Kaharingan lima B yakni bahenda (kuning), baputi (putih), bahandang (merah), bahijau (hijau), dan babilem (hitam).

I) Warna kuning melambangkan keagungan, kekuasaan Yang Maha Agung, bijaksana, adil, pengasih dan penyayang atau warna yang melambangkan betapa agungnya kuasa Tuhan bagi kehidupan manusia.

2) Warna putih melambangkan kesucian yang abadi, tulus ikhlas tanpa noda dari pengaruh apapun.

3) Warna merah melambangkan keberanian yang dilandasi kebenaran. Seperti ungkapan dalam bahasa Dayak Ngaju : Ela tende manggetu hinting bunu penjang, isen mulang maneten kamara ambu yang artinya jangan berhenti berjuang, walaupun sampai tetes darah terakhir dalam mencapat kehidupan bersama bahagia sejahtera, lepas dari segala kemiskinan.

4) Warna hijau melambangkan ketulusan, keramahan (kajenta kajurah), kelembutan dari alam ciptaan Tuhan terhadap kehidupan manusia.

5) Warna hitam melambangkan alam kehidupan manusia. Kehidupan memang penuh dengan segala tantangan. Hitam adalah kegelapan. Warna gelap atau hitam sering kita lihat dipakai pada saat-saat pengobatan orang sakit. Penyakit dan pengatuh-pengaruh buruk dilambangkan dengan warna hitam. Sesuatu yang hitam, dikembalikan ke hitam.

Daun sawang adalah lambang dari perwujudan kuasa Tuhan, memberikan kekuatan, guna 
menghadapi segala kesulitan atau masalah dalam kehidupan manusia.

\section{KESIMPULAN}

Manajah Antang berasal dari kata Manajah dan antang; manajah berasal dari kata dasar tajah yang artinya tanda atau alamat untuk mendapatkan petunjuk. Jadi Manajah Antang adalah suatu kegiatan mencari pertanda atau meminta petunjuk dengan menggunakan antang (bahasa Dayak Ngaju : Elang) sebagai manisfestasi kekuasaan Yang Maha Kuasa bagi kehidupan manusia. Ritual ini bertujuan mengetahui:

I. Di mana tempat yang menguntungkan jika akan berusaha

2. Ke mana arah merantau yang menguntungkan

3. Di mana tempat berladang yang baik

4. Bagaimana cara mengobati sakit seseorang

5. Di mana tempat yang cocok untuk membangun kampung

6. Dalam hal terjadinya peperangan

7. Dalam hal mencari tempat terjadinya musibah

Upacara adat tradisional Manajah Antang merupakan upacara adat turun temurun yang dipimpin oleh seorang Damang Kepala Adat atau Tetua Adat, dengan memanggil Antang Tajahan yang menurut kepercayaan Suku Dayak Katingan memiliki kesaktian yang di luar kemampuan manusia dalam upaya membantu atau meminta petunjuk terhadap permasalahan yang mereka hadapi.

Masyarakat Suku Dayak Katingan menyadari bahwa aktivitas tersebut merupakan pengakuan terhadap keberadaan, kekuasaan dan kasih sayang dari Yang Maha Besar Tuhan, bentuk kesadaran akan adanya saling ketergantungan antara semua biota yang terdapat di alam semesta ini sebagai mahkluk ciptaan Tuhan serta upaya menjaga kelestarian dan keseimbangan lingkungan hidup, agar mendapatkan kehidupan yang serasi, selaras dan seimbang.
Berdasarkan hasil analisa dan interprestasi bahwa tujuan penyelenggaraan Upacara Adat tradisional Manajah Antang di anggap mengandung makna untuk membantu mengatasi kesulitan masyarakat. Kemudian manfaat dari pelaksanaan Upacara Adat tradisional Manajah Antang dapat menimbulkan rasa aman, bisa memberikan petunjuk, dapat membawa keselamatan bagi yang melakukan perjalanan jauh sehingga sampai ketujuan, dapat meningkatkan kehidupan sosial masyarakat, serta dapat memberikan penghidupan yang lebih layak dalam membuka lahan bagi masyarakat.

\section{UCAPAN TERIMA KASIH}

Kami mengucapkan banyak terima kasih kepada Demang Kepala Adat Kasongan Kabupaten Katingan, Mantir Adat Kasongan Kabupaten Katingan, Masyarakat Adat Kasongan Kabupaten Katingan yang sudah membantu dalam pengumpulan data dan informasi, serta Bapak Dekan Fakultas Keguruan dan Ilmu Kependidikan Universitas PGRI Palangka Raya yang telah memberikan izin penelitian.

\section{REFERENSI}

Batuallo, Salmon. 2015. Peranan Nilai Budaya Masyarakat Dayak Ngaju dalam Memelihara Lingkungan Di Provinsi Kalimnatan Tengah. Palangka Raya: Departemen Kebudayaan dan Pariwisata Kalimantan Tengah.

Dinas pendidikan dan Kebudayaan Provinsi Kalimantan Tengah. 2007. Upacara Tradisional Daerah Kalimantan Tengah Bagian I. Palangka Raya: CV Primal Indah

Hubberman, Michael dan Milles. 1992. Analisis Data Kualitatif. Jakarta: UI Press.

BPS Katingan. 2017. Kabupaten Katingan Dalam Angka

Kerukunan Keluarga Dayak Kalteng (KKD-KT) dan Dinas Pendidikan Kebudayaan Prov. Kalimantan Tengah. 2008. Upon Ajar Bahasa Dayak Ngaju.

Koentjaraningrat. 2000. Kebudayaan, Mentalitas, dan Pembangunan. Jakarta: PT GramediaPustakaUtama. 
Rampai, D. Kiwok.1984. Upacara Tradisional Dalam Kaitannya Dengan Peristiwa Alam dan Kepercayaan Daerah Kalimantan Tengah. Depertemen Pendidikan dan Kebudayaan

Mohammad Nazir. 2005. Metode Penelitian. Bogor: Galia Indonesia

Moleong, Lexy J. 20II. Metodologi Penelitian Kualitatif. Bandung: Remaja Rosdakarya

Sekretaris Negara. 1988. Garis-Garis Besar Haluan Negara

Sugiyono. (2013). Memahami Penelitian Kualitatif. Bandung: Alfabeta.

Tjilik Riwut. 2007. Kalimantan Membangun Alam dan Kebudayaan. Yogjakarta: NR Publishing 